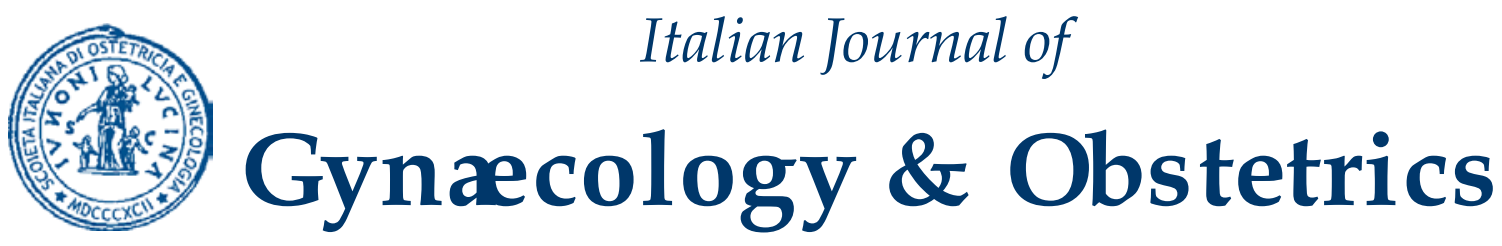

June 2020 - Vol. 32 - N. 2 - Quarterly - ISSN 2385 - 0868

\title{
The role of serum potassium and sodium levels in the development of postpartum hemorrhage. A retrospective study
}

\author{
A. A. Privitera ${ }^{1}$, M. Fiore ${ }^{2}$, G. Valenti ${ }^{1}$, S. Raniolo ${ }^{1}$, A. Schiattarella 3 , G. Riemma ${ }^{3}$, G. Gullo ${ }^{4}$,

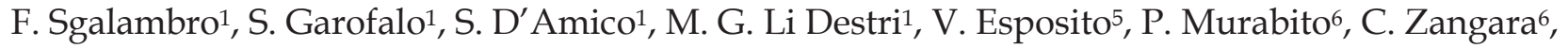 \\ M. Fichera ${ }^{1}$
}

${ }^{1}$ Department of General Surgery and Medical Surgical Specialties, University of Catania, Catania, Italy

2Department of Medical, Surgical Sciences and Advanced Technologies G. F. Ingrassia, Catania University, Catania, Italy

3Department of Woman, Child and General and Specialized Surgery, University of Campania Luigi Vanvitelli, Naples, Italy

4Department of Obstetrics and Gynecology, AOOR Villa Sofia Cervello, IVF Public Center, Palermo, Italy

${ }^{5}$ Department of Gynecology and Obstetrics, San Giuseppe Hospital, University of Milan, Milan, Italy

${ }^{6}$ Department of Anaesthesiology, University of Catania, Catania, Italy

\begin{abstract}
Objectives. Primary postpartum hemorrhage (PPH) represents the first responsible cause of maternal mortality, leading at least a quarter of deaths during childbirth and in the puerperium. Most cases of PPH occur in women who do not have distinct risk factors. Voltage-gated ions channels, particularly the potassium channels, play an essential role in contractility regulation of the uterus. The aim of our study was to identify the possible role of the pre-delivery serum sodium $(\mathrm{Na}+)$, potassium $(\mathrm{K}+)$ electrolytes levels and $\mathrm{Na} * \mathrm{~K}$ product in $\mathrm{PPH}$.

Methods. We conducted a single-institution retrospective study on all patients consecutively referred to our institution for spontaneous delivery between 1 January 2011 and 31 December 2018. Among these, patients with PPH were compared to controls patients selected according to specific inclusion-exclusion criteria. All information regarding patient's characteristics were retrospectively collected, particularly, pre-delivery blood tests, including serum electrolytes (such as $\mathrm{K}+$ and $\mathrm{Na}+$ ) were recorded and compared
\end{abstract}

between cases and controls by Chi-square and U MannWhitney tests, as appropriate. Logistic regression analysis was used to estimate the odds ratios (ORs) and 95\% confidence intervals (CIs) of PPH associated with $\mathrm{Na}+, \mathrm{K}+$ and $\mathrm{Na}{ }^{*} \mathrm{~K}$ serum levels. In the analysis a crude (simple) and an adjusted model (adjusted for episiotomy and perineal laceration) were used. To evaluate the best $\mathrm{PPH}$ predictive score, a ROC curve (Receiver Operating Characteristic) was used.

Results. A lower statistically significant serum level of $\mathrm{K}+$ and $\mathrm{Na}^{*} \mathrm{~K}$ product were recorded among the primary $\mathrm{PPH}$ cases compared to the control group $(p<0.001)$. The adjusted ORs $(95 \% \mathrm{CI})$ for $\mathrm{K}+$ and the product $\mathrm{Na} * \mathrm{~K}$ were 19.40 (95\% CI 2.40-156) and 8.78 (95\% CI 1.96-39), respectively.

Conclusions. A level of electrolytes, particularly for $\mathrm{K}+$ serum level, lower than the non-pregnancy threshold/median, could be considered as a possible pre-delivery risk factor for primary $\mathrm{PPH}$. 


\section{SOMMARIO}

Obiettivi. L'emorragia primaria del postpartum (PPH) rappresenta la prima causa di mortalità materna, provocando almeno un quarto dei decessi durante il parto e il puerperio. La maggior parte dei casi di PPH primaria si verifica in donne che non presentano fattori di rischio evidenti. I canali degli ioni dipendenti dalla tensione, in particolare i canali del potassio, svolgono un ruolo essenziale nella regolazione della contrattilità dell'utero. Lo scopo del nostro studio era di identificare il possibile ruolo del valore sierico pre-parto di elettroliti quali sodio $(\mathrm{Na}+)$, potassio $(\mathrm{K}+)$ e del loro prodotto $\left(\mathrm{Na}^{*} \mathrm{~K}\right)$ nella $\mathrm{PPH}$ primaria.

Metodi. Abbiamo condotto uno studio retrospettivo su tutti i pazienti afferiti consecutivamente al nostro Centro per l'espletamento del parto spontaneo, tra il $1^{\circ}$ gennaio 2011 e il 31 Dicembre 2018. Tra questi, i pazienti con PPH primaria sono stati confrontati con i controlli selezionati in base a specifici criteri di inclusione-esclusione. Tutte le informazioni relative alle caratteristiche delle pazienti sono state raccolte in modo retrospettivo (tramite le cartelle clini- che), in particolare sono stati presi in considerazione gli esami del sangue pre-parto, compresi gli elettroliti sierici (come $\mathrm{K}+\mathrm{e} \mathrm{Na}+$ ). Quindi, i due gruppi sono stati confrontati mediante i test Chi-quadrato e U Mann-Whitney.

Il rischio di PPH in relazione ai livelli sierici di $\mathrm{Na}+, \mathrm{K}+\mathrm{e}$ $\mathrm{Na}$ K è stato stimato utilizzando modelli di regressione logistica grezzi e multivariati. Infine, per stimare il cut off, degli elettroliti indagati, predittivo di PPH è stata utilizzata la curva ROC (Receiver Operating Characteristic).

Risultati. Sono stati riscontrati valori sierici di $\mathrm{K}+$ e del prodotto $\mathrm{Na} * \mathrm{~K}$ statisticamente più bassi nel gruppo con $\mathrm{PPH}$ primaria rispetto al gruppo di controllo $(\mathrm{p}<0.001)$.

Gli ORadj per il $\mathrm{K}+$ e per il prodotto $\mathrm{Na}$ K erano rispettivamente 19,4 (95\% IC 2.40-156) e 8,78 (95\% IC 1.96-39).

Conclusioni. I livelli sierici di elettroliti, in particolare quello del $\mathrm{K}+$, al di sotto del valore soglia/mediana, potrebbe essere considerato un possibile fattore di rischio preparto per la PPH primaria.
Corresponding Author: Gaetano Valenti valentigaetano@gmail.com

Copyright 2020

DOI: $10.36129 /$ jog.32.02.05
Key words: hypokalemia; maternal mortality; postpartum hemorrhage; potassium; potassium channels; sodium 


\section{INTRODUCTION}

Primary postpartum hemorrhage (PPH) is defined, by the World Health Organization (WHO), as blood loss greater or equal to $500 \mathrm{~mL}$ and $1000 \mathrm{~mL}$, within the 24 hours, after vaginal delivery and cesarean section, respectively (1-7). Postpartum hemorrhage has a worldwide prevalence of $3-5 \%$ and is the first cause of maternal mortality, especially in low-income countries, being responsible for at least a quarter of deaths during childbirth and puerperium (8-13). Most cases of PPH occur in women who do not have distinct risk factors. The most common cause is uterine atony (about 70\% of cases), followed by perineal and vaginal tears and/ or trauma (20\%), placenta tissue retention, placental abnormalities $(9 \%)$, and coagulopathies $(1 \%)(6,8,11,14,15)$. In clinical practice, they are summarized as the "4Ts": tone, tissue, trauma and thrombin $(2,10,12,16)$. Complications of postpartum hemorrhage are: anemia, blood transfusion, dilutional coagulopathy, Sheehan syndrome or postpartum pituitary necrosis, fatigue, myocardial ischemia, orthostatic hypotension, postpartum depression, and death (5,16-20). However, the molecular mechanisms behind the most common cause of primary $\mathrm{PPH}$ are not well understood. A fundamental role is played by oxytocin that acts not only as a ligand for specific membrane receptors but also as a ligand of calcium channels, modulating both the myosin light chain kinase (MLCK), the myosin phosphatase, and the release of inositol trisphosphate (IP3). The outcome of these mechanisms is the increase in $\mathrm{Ca}++$ level, which triggers uterine contraction (21-23). Calcium also depolarizes the plasma membrane of the smooth uterine cells, allowing the activation of voltage-gated potassium and sodium channels $(23,24)$. During pregnancy, the uterus is quiescent and non-responsive, and it has a hyperpolarized membrane potential that is close to that of potassium $(25,26)$. Conversely, at the end of pregnancy and during the labor, myocellular depolarization occurs with the development of uterine contractions (26). There is a common agreement that voltage-gated ions channels, particularly the potassium one, play an essential role in the regulation of the membrane potential and, therefore, in the contractility of the human uterus (27). Specifically, the Kir 7.1 potassium channel has demonstrated to play a critical role in regulating uterine excitability during pregnancy and might be involved in some PPH cases $(28,29)$. Studies have long focused on the role of potassium channels in uterine contractility, but it is not clear at all the relationship with $\mathrm{PPH}(26,30-32)$. The aim of our study was to identify the possible role of the predelivery levels of sodium $(\mathrm{Na}+)$ and potassium $(\mathrm{K}+)$ serum electrolytes in the PPH development.

\section{MATERIALS AND METHODS}

This is a retrospective study of pregnant women reported with primary $\mathrm{PPH}$ and compared with healthy controls. The study was conducted according to STROBE (Strengthening the reporting of observational studies in epidemiology guidelines (33).

\section{POPULATION SELECTION CRITERIA}

After obtaining approval by the Institutional Review Board of the "Policlinico G. Rodolico-Vittorio Emanuele" Hospital of Catania, Italy, all consecutive pregnant women who referred to Obstetrics and Gynecology department for spontaneous vaginal delivery, between 1 January 2011 and 31 December 2018, were identified and considered into the analysis. Among eligible patients, patients with primary $\mathrm{PPH}$ were selected and considered as "cases"; patients without PPH were considered as "controls" according to the inclusion/exclusion criteria and included with a ratio 1:4 (table I).

Table 1. Inclusion and exclusion criteria

Inclusion criteria

\begin{tabular}{l}
\hline \multicolumn{1}{c}{ Inclusion criteria } \\
\hline - $\quad \begin{array}{l}\text { Delivery between } 37^{\circ} \text { and } 41^{\circ}+6 \\
\text { week of gestational age } \\
\text { Age between } 15 \text { and } 45 \text { years } \\
\text { - } \quad \text { Spontaneous vaginal delivery and } \\
\text { caesarean section }\end{array}$ \\
- $\quad \begin{array}{l}\text { Exclusion criteria } \\
\text { Structural defects } \\
\text { Previous surgery at the uterus and/ } \\
\text { or at the genitourinary tract } \\
\text { Diabetes mellitus }\end{array}$ \\
\hline
\end{tabular}


- Hyperaldosteronism or other electrolytes disorders

- Maternal kidney disease

- Coagulation disorders

- $\quad$ Multiple pregnancy

- Foetal macrosomia

- Preeclampsia or eclampsia

- Chorioamnionitis

- Delay and complications in second stage of labour

- Previous postpartum haemorrhage

- Genital tract lacerations

- Extension of episiotomy

- Placental retention

- Uterine inversion

- Prolongation of third stage of labour

- $\quad$ Retained placenta

- $\quad$ Placenta accreta

\section{DATA EXTRACTION}

Data were collected by direct consultation of the hospital medical records, ICD codes n. $666 / 01 / 02 / 03$. All information regarding the characteristics of the patients were retrospectively collected and inserted in a dedicated electronic database. This included age, personal medical/clinical and obstetric history, serum electrolytes $(\mathrm{K}+$ and $\mathrm{Na}+$ at least), risk factors for $\mathrm{PPH}$, data for each pregnancy (delivery modes, delivery, and postpartum complications like PPH and pregnancy outcomes).

\section{VARIABLES AND OUTCOMES}

Sodium and potassium serum levels before the delivery were considered primary independent variables, whereas the product of sodium and potassium $\left(\mathrm{Na}^{*} \mathrm{~K}\right)$ was evaluated as secondary independent variable. Although, hypokalemia is defined as a serum potassium level less than 3.5 $\mathrm{mEq} / \mathrm{L}$ and hyponatremia is defined as a serum sodium level less than $135 \mathrm{mEq} / \mathrm{L}$, the outcome of our study was the difference in absolute average serum level of these serum electrolytes between cases and controls, with no regards to a conventional electrolytes cut-off. We considered episiotomy and perineal laceration as potential confounders of primary PPH so we included them in the multivariate analysis. The estimation of blood loss was quantified using calibrated under-buttocks drape folds.

\section{STATISTICAL ANALYSIS}

Statistical analysis was performed using SPSS for Windows (Statistical Package for the Social Science, version 21.0; SPSS Inc., Chicago, IL, USA). The level of significance was set at $\mathrm{p}<0.05$. Absolute and relative frequency distribution as well as contingency tables were created. Continuous variables were expressed as median (Interquartile range). The differences between groups (cases and controls) were evaluated using nonparametric tests such as Chi-square and MannWhitney. Subsequently, a multivariate analysis was conducted, using a logistic regression model to analyze which risk factors were independently associated with PPH. To evaluate the best PPH predictive score, a ROC curve (Receiver Operating Characteristic) was used.

\section{RESULTS}

Among 4270 patients assessed for eligibility, only 130 patients were included in the analysis. Twenty-three patients were excluded due to data missing, whereas 3988 due to inclusion/exclusion criteria. Finally, we included in the study 26 cases with primary PPH and 104 controls (figure 1).

Figure 1 - Study flow chart.

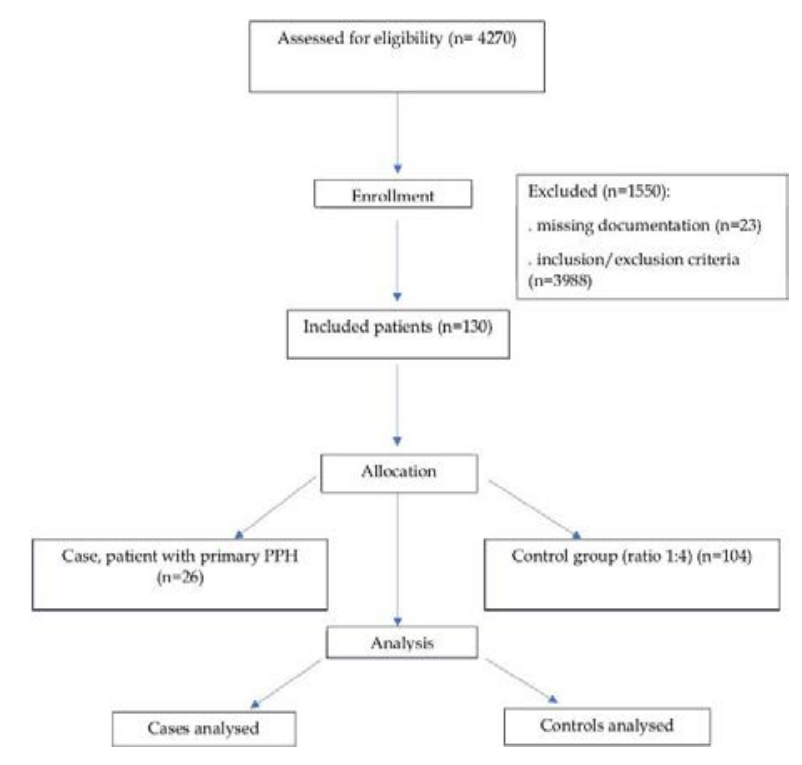


Patients' characteristics were reported in table II. Vaginal delivery was slightly but statistically more present among the case group, whereas Cesarean section was slightly higher in the control group $(p=0.022)$. There was no other statistical difference between the two groups.

Table II. Main characteristics of study population.

\begin{tabular}{|c|c|c|c|}
\hline & $\begin{array}{l}\text { Case } \\
(\mathrm{N}=26)\end{array}$ & $\begin{array}{l}\text { Control } \\
(\mathrm{N}=104)\end{array}$ & p-value \\
\hline Age & $32.4 \pm 2.5$ & $31.9 \pm 3.7$ & $0.516^{*}$ \\
\hline \multicolumn{4}{|l|}{$\begin{array}{l}\text { Number of } \\
\text { previous } \\
\text { pregnancies }\end{array}$} \\
\hline None & $14(53.8)$ & $45(43.3)$ & \multirow[t]{2}{*}{$0.338^{\wedge}$} \\
\hline 1 or more & $12(46.2)$ & $59(56.6)$ & \\
\hline $\begin{array}{l}\text { Number of } \\
\text { previous } \\
\text { pregnancies }\end{array}$ & $3.2 \pm 1.2$ & $2.8 \pm 1.4$ & $0.183^{*}$ \\
\hline \multicolumn{4}{|l|}{$\begin{array}{l}\text { Mode of delivery } \\
\text { method }\end{array}$} \\
\hline Vaginal deliery & $22(84.0)$ & $62(60)$ & \multirow[t]{2}{*}{$0.022^{\wedge}$} \\
\hline Cesarean section & $4(16.0)$ & $42(40)$ & \\
\hline \multicolumn{4}{|l|}{$\begin{array}{l}\text { Apgar score at } 5 \\
\text { minutes }\end{array}$} \\
\hline$\geq 8$ & $25(96.2)$ & $100(97)$ & \multirow[t]{2}{*}{$0.835^{\wedge}$} \\
\hline$\leq 7$ & $1(3.8)$ & $4(3)$ & \\
\hline $\begin{array}{l}\text { Blood transfusion } \\
\text { (yes) }\end{array}$ & $5(19.2)$ & $0(0)$ & ** \\
\hline
\end{tabular}

Data are expressed as mean \pm standard deviation or as frequencies (percentages). ${ }^{\wedge}$ Chi-square sêp test

*Mann-Whitney test

${ }^{*}$ Due to the zero frequency, the $p$ value is not provided.

Confounders, such as episiotomy and perineal laceration, show no statistical difference between the two groups (table III).

Table III. Distribution of the confounders by cases and controls.

\begin{tabular}{|r|c|c|c|}
\hline Variable & $\begin{array}{l}\text { Case } \\
(\mathrm{N}=26) \\
\mathrm{n}(\%)\end{array}$ & $\begin{array}{c}\text { Control } \\
(\mathrm{N}=104) \\
\mathrm{n}(\%)\end{array}$ & p-value $^{*}$ \\
\hline Episiotomy & & & \\
\hline Yes & $8(30)$ & $\begin{array}{c}35 \\
(33.5)\end{array}$ & 0.735 \\
\hline No & $18(70)$ & $\begin{array}{c}69 \\
(66.5)\end{array}$ & \\
\hline $\begin{array}{l}\text { Perineal } \\
\text { laceration }\end{array}$ & & & \\
\hline Yes & $1(4)$ & $\begin{array}{c}15 \\
(14.5)\end{array}$ & 0.148 \\
\hline No & $25(96)$ & $\begin{array}{c}89 \\
(85.5)\end{array}$ & \\
\hline
\end{tabular}

${ }^{*}$ Chisquare test.

The medians and the interquartile range of $\mathrm{Na}$, $\mathrm{K}+$, and $\mathrm{Na}^{*} \mathrm{~K}$, of both groups, were evaluated. Both the $\mathrm{K}+$ level and the product $\mathrm{Na}^{*} \mathrm{~K}$ in pa- tients with $\mathrm{PPH}$ were significantly lower compared to the control group $\mathrm{p}<0.001$. Conversely, no differences were found between the two groups concerning the $\mathrm{Na}+$ level (table IV).

Table IV. Medians and interquartile intervals of $\mathrm{Na}+\mathrm{K}+$, and $\mathrm{Na}^{*} \mathrm{~K}$.

\begin{tabular}{|l|c|c|c|c|}
\hline \multirow{2}{*}{ Variable } & \multicolumn{3}{|c|}{$\begin{array}{c}\text { Median } \\
\text { (IQR*) }\end{array}$} & \multirow{2}{*}{$\begin{array}{c}\text { p-va- } \\
\text { lue** }\end{array}$} \\
\cline { 2 - 4 } & Total & $\begin{array}{c}\text { Cases } \\
\mathrm{n}=26\end{array}$ & $\begin{array}{c}\text { Controls } \\
\mathrm{n}=104\end{array}$ & \\
\hline Sodium & 137 & 138 & 137 & 0.289 \\
(meq/L) & $(135-139)$ & $(134-139)$ & $(135-139)$ & \\
\hline Potassium & 4.1 & 3.8 & 4.1 & 0.000 \\
(meq/L) & $(3.9-4.3)$ & $(3.7-4.0)$ & $(3.9-4.3)$ & \\
\hline Na*K & 554 & 524 & 557 & 0.000 \\
(meq/L) & $(530-589)$ & $(496-552)$ & $(532-593)$ & \\
\hline
\end{tabular}

*IQR: interquartile range ** U Mann-Whitney test.

We have found a positive association with potassium (OR=19, 95\% CI 2.40-157) and $\mathrm{Na}^{*} \mathrm{~K}$ product levels (OR= 8.78, 95 \% CI 1.96-39) (table V). Conversely, $\mathrm{Na}+$ has not showed a statistically significant risk (data not furnished) to develop PPH. Due to the strong association between the low serum level of $\mathrm{K}+$ and $\mathrm{Na}^{*} \mathrm{~K}$ product and the risk to develop PPH, the ROC curve was used in order to evaluate a possible diagnostic and predictive role of these electrolytes, especially for serum potassium level.

Table V. Odds ratio (OR) with 95\% confidence interval (CI) of primary postpartum hemorrhage risk according to $\mathrm{Na}+, \mathrm{K}+$, and $\mathrm{Na}^{*} \mathrm{~K}$ product.

\begin{tabular}{|c|c|c|c|c|}
\hline Variable & $\begin{array}{l}\text { Case } \\
\mathrm{N}=26\end{array}$ & $\begin{array}{l}\text { Control } \\
\mathrm{N}=252\end{array}$ & $\begin{array}{l}\text { OR } \\
\text { (IC 95\%) }\end{array}$ & $\begin{array}{c}\text { OR adj1 } \\
\text { (IC 95\%) }\end{array}$ \\
\hline $\begin{array}{l}\text { Sodium } \\
(\mathrm{mEq} / \mathrm{L})\end{array}$ & & & & \\
\hline$\geq 138$ & $14(53.8)$ & $97(38.5)$ & $*$ & $*$ \\
\hline$\leq 137$ & $12(46.2)$ & $155(61.5)$ & $\begin{array}{c}0.54 \\
(0.24-1.20)\end{array}$ & $\begin{array}{c}0.284 \\
(0.093- \\
0.867)\end{array}$ \\
\hline $\begin{array}{c}\text { Potassium } \\
(\mathrm{mEq} / \mathrm{L})\end{array}$ & & & & \\
\hline$\geq 4.2$ & $2(7.7)$ & $108(43.2)$ & $*$ & $*$ \\
\hline$\leq 4.1$ & $24(92.3)$ & $142(56.8)$ & $\begin{array}{c}9.13 \\
(2.11-39.5)\end{array}$ & $\begin{array}{c}19.40 \\
(2.40-156.5)\end{array}$ \\
\hline $\begin{array}{c}\mathbf{N a} \mathbf{K} \\
(\mathrm{mEq} / \mathrm{L})\end{array}$ & & & & \\
\hline$\geq 555$ & $4(15.4)$ & $133(53.0)$ & ${ }^{*}$ & $*$ \\
\hline$\leq 554$ & $22(84.6)$ & $118(47.0)$ & $\begin{array}{c}6.2 \\
(2.1-18.5)\end{array}$ & $\begin{array}{c}8.78 \\
(1.96-39.4)\end{array}$ \\
\hline
\end{tabular}

Data are expressed as frequencies (percentages).

*reference category: each odds ratio is adjusted for episiotomy and perineal laceration.

From the analysis of the ROC curve (figure 2), it can be seen that none of the electrolytes 
investigated were able to discriminate between women who developed PPH or not, and therefore, they cannot be used as a diagnostic test.

Figure 2 - Receiver operating curve (ROC) of $\mathrm{Na}+\mathrm{K}+$ and $\mathrm{Na} * \mathrm{~K}$ product serum levels as predictors of primary postpartum hemorrhage.

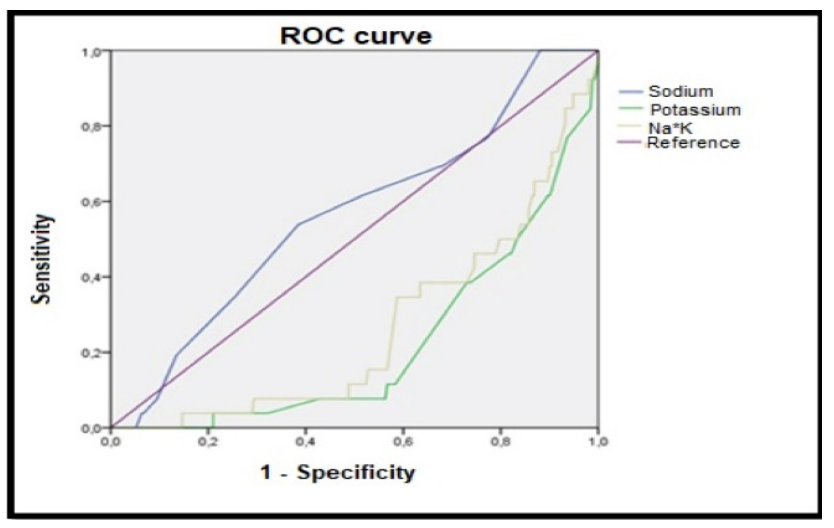

\section{DISCUSSION}

Our findings showed that reduced serum $\mathrm{K}+$ levels could influence the risk of developing PPH. This point was not extensively analyzed before in the literature, although the role of potassium during pregnancy is widely studied (34-36). In fact, the altered potassium level in pregnancy was associated with an increased risk for atherosclerosis and is also a predictive factor for renal dysfunction, gestational diabetes mellitus and, hypertensive disorders (37-43). The myometrial contraction critically depends on the control of calcium entry through voltage-gated L- and T-type calcium channels $(21,22)$. Calcium is not only an essential second messenger for contraction via calcium-calmodulin-dependent myosin light chain kinase, but also depolarizes the plasma membrane, with activation of other voltage-dependent ion channels $(32,44)$. The control of uterine excitability is finely modulated during pregnancy. In particular, mid-gestation is characterized by the presence of hyperpolarized membrane potential close to the reversal potential for potassium Ek (45). At term, the myometrium becomes increasingly depolarized, to approximately $45 \mathrm{mV}$ at parturition $(23,45)$. This crucial mechanism remains unknown. Moreover, there has been a growing interest in the role of potassium channels such as Kir 7.1, an inwardly rectifying $\mathrm{K}+$ channel, especially in the pathophysiology of postpartum hemorrhage $(28,30)$. Kir 7.1 represents a crucial regulator of membrane potential in uterine myocytes during pregnancy: high expression of Kir 7.1 keeps the resting membrane potential near to the reversal potential for potassium, thus increasing the depolarizing drive required to initiate an action potential, calcium entry, and subsequent contraction. At the term of pregnancy, this damping of excitability is lost by reduction but not a complete loss, of Kir 7.1. However, some authors found out the potential therapeutic benefit of inhibiting Kir 7.1 during oxytocin administration for postpartum hemorrhage $(29,30,46,47)$. Serum potassium level is mainly regulated by renal potassium excretion, particularly by cells of the collecting duct. The factors that influence potassium excretion are high aldosterone level, high distal delivery of sodium to the collecting duct, and high negativity of the lumen in the collecting duct $(48,49)$. Potassium metabolism during pregnancy is not fully understood. During a healthy pregnancy, the secretion of aldosterone is enhanced, and one of the causes is the increase of splanchnic and systemic vasodilatation (49). However, the high levels of progesterone act as mineral corticoid receptor blocker, and by that decrease, the full effect of aldosterone on the kidney and severe potassium wasting is avoided $(31,49)$. During a healthy pregnancy, the glomerular filtration ratio (GFR) is modified (50-52). According to the literature, we evaluated the role of serum electrolytes during the third trimester of pregnancy, in order to identify a range of serum sodium levels that could act as a predictive risk factor for $\mathrm{PPH}$. Our findings showed that reduced serum $\mathrm{K}+$ levels, regardless of the range of values considered physiological outside of pregnancy, could influence the risk of developing postpartum hemorrhage. $\mathrm{Na}+$ alone is not able to determine significant changes in uterine contractility and, therefore, at the risk of developing a PPH. However, our data are limited by the small number of patients selected in the case group due to the low frequency of the $\mathrm{PPH}$ in our setting. A multicentric retrospective study should be performed to understand the role of electrolytes in PPH better. Physiological changes during pregnancy influence normal biochemical values: for example, serum thyroid-stimulating hormone (TSH) value varies, especially during the first trimester, and no cut-off value is universally accepted. However, thyroid hormones are widely accepted as essential factors for the neurodevelopment of the children $(53,54)$. The ORadj is adjusted odds ratio (AOR), further 
confirming the role of serum electrolytes in the alteration of uterine contractility and in the risk of primary PPH. In our study, we also performed a ROC curve to evaluate the possibility of using the electrolytes as a possible diagnostic and predictive PPH test. However, the results showed that the electrolytes could not be used as a diagnostic test for PPH. The management of $\mathrm{PPH}$ remains a topic of great debate, and new diagnostic and therapeutic possibilities in recent years underline this aspect. However, the avail-able evidence is still scarce and the stan- dard values are lacking $(12,14,55)$. This preliminary study focused on potassium as a crucial actor for myometrial contraction; however, it underlines the attention for serum values during the pregnancy to reduce the risk of $\mathrm{PPH}$, also by considering oral supplementation.

\section{CONFLICT OF INTERESTS}

The authors declare that they have no conflict of interest. 


\section{REFERENCES}

(1) Mousa HA, Blum J, Abou El Senoun G, et al. Treatment for primary postpartum haemorrhage. Cochrane Database Syst Rev 2014:CD003249.

(2) Russell RT. WHO guidelines for the management of postpartum haemorrhage and retained placenta. Hum Fertil 2011;14:129-129.

(3) Rousset P, Rousset-Jablonski C, Alifano M, et al. Thoracic endometriosis syndrome: CT and MRI features. Clin Radiol 2014;69:323-330. (4) American College of Obstetricians and Gynecologists. ACOG Practice Bulletin No. 76: Postpartum Hemorrhage. Obstet. Gynecol. 2006;108:1039-1048.

(5) Leduc D, Senikas V, Lalonde AB. No. 235-Active Management of the Third Stage of Labour: Prevention and Treatment of Postpartum Hemorrhage. J Obstet Gynaecol Can 2018;40:e841e855.

(6) Tsu VD, Langer A, Aldrich T. Postpartum hemorrhage in developing countries: is the public health community using the right tools? Int J Gynecol Obstet 2004;85:S42-S51.

(7) Rossetti D, Vitale SG, Gulino FA, et al. Pelvic arterial embolization for postpartum hemorrhage: long term results of a single center experience in 29,091 deliveries. Clin Exp Obstet Gynecol 2016;43:733-736.

(8) Jakobovits A, Sama J. Postpartum hemorrhage. Oper. Obstet. Third Ed., CRC Press, 2006:265-280.

(9) Dahlke JD, Mendez-Figueroa H, Maggio L, et al. Prevention and management of postpartum hemorrhage: a comparison of 4 national guidelines. Am J Obstet Gynecol 2015;213:76.e176.e10.

(10) Zea-Prado F, Hernández-Pacheco J, OrtizRamírez M, et al. Initial management of primary postpartum hemorrhage: a survey. J Matern-Fetal Neonatal Med Off J Eur Assoc Perinat Med Fed Asia Ocean Perinat Soc Int Soc Perinat Obstet 2019:1-7.

(11) Ramler PI, Henriquez DDCA, van den Akker $\mathrm{T}$, et al. Comparison of outcome between intrauterine balloon tamponade and uterine artery embolization in the management of persistent postpartum hemorrhage: A propensity scorematched cohort study. Acta Obstet Gynecol Scand 2019;98:1473-1482.
(12) Evensen A, Anderson JM, Fontaine P. Postpartum Hemorrhage: Prevention and Treatment. Am Fam Physician 2017;95:442-449. (13) Affronti G, Giardina I, Epicoco G, et al. A conservative protocol for the management of postpartum hemorrhage. Evaluation of its effectiveness in high risk patients. Ital J Gynaecol Obstet 2014;26:19-23.

(14) Affronti G, Agostini V, Brizzi A, et al. The daily-practiced post-partum hemorrhage management: an Italian multidisciplinary attended protocol. Clin Ter 2017;168:e307-e316.

(15) Rossetti D, Vitale SG, Bogani G, et al. Usefulness of vessel-sealing devices for peripartum hysterectomy: a retrospective cohort study. Updat Surg 2015;67:301-304.

(16) Kerr R, Weeks A. Postpartum haemorrhage: a single definition is no longer enough. BJOG Int J Obstet Gynaecol 2017;124:723-726.

(17) Clark SL, Belfort MA, Dildy GA, et al. Maternal death in the 21st century: causes, prevention, and relationship to cesarean delivery. Am J Obstet Gynecol 2008;199:36.e1-5; discussion 912. e7-11.

(18) Ahonen J, Stefanovic V, Lassila R. Management of post-partum haemorrhage. Acta Anaesthesiol Scand 2010;54:1164-1178.

(19) Vitale SG, Laganà AS, Muscatello MRA, et al. Psychopharmacotherapy in Pregnancy and Breastfeeding. Obstet Gynecol Surv 2016;71:721733.

(20) Bruno A, Laganà AS, Leonardi V, et al. Inside-out: the role of anger experience and expression in the development of postpartum mood disorders. J Matern-Fetal Neonatal Med Off J Eur Assoc Perinat Med Fed Asia Ocean Perinat Soc Int Soc Perinat Obstet 2018;31:30333038.

(21) Amédée T, Mironneau C, Mironneau J. The calcium channel current of pregnant rat single myometrial cells in short-term primary culture. J Physiol 1987;392:253-272.

(22) Blanks AM, Zhao Z-H, Shmygol A, et al. Characterization of the molecular and electrophysiological properties of the T-type calcium channel in human myometrium. J Physiol 2007;581:915-926.

(23) Parkington HC, Tonta MA, Brennecke SP, et al. Contractile activity, membrane potential, and cytoplasmic calcium in human uterine smooth muscle in the third trimester of pregnancy and 
during labor. Am J Obstet Gynecol 1999;181:1445-1451.

(24) Revankar CM, Cimino DF, Sklar LA, et al. A transmembrane intracellular estrogen receptor mediates rapid cell signaling. Science 2005;307:1625-1630.

(25) Wray S, Prendergast C. The Myometrium: From Excitation to Contractions and Labour. Adv Exp Med Biol 2019;1124:233-263.

(26) Choi Y, Seo H, Shim J, et al. Calcium extrusion regulatory molecules: differential expression during pregnancy in the porcine uterus. Domest Anim Endocrinol 2014;47:1-10.

(27) Loftus FC, Richardson MJE, Shmygol A. Single-cell mechanics and calcium signalling in organotypic slices of human myometrium. J Biomech 2015;48:1620-1624.

(28) Nakamura N, Suzuki Y, Sakuta H, et al. Inwardly rectifying $\mathrm{K}+$ channel Kir7.1 is highly expressed in thyroid follicular cells, intestinal epithelial cells and choroid plexus epithelial cells: implication for a functional coupling with $\mathrm{Na}+, \mathrm{K}+$-ATPase. Biochem J 1999;342 (Pt 2:329_ 336.

(29) Bhave G, Chauder BA, Liu W, et al. Development of a selective small-molecule inhibitor of Kir1.1, the renal outer medullary potassium channel. Mol Pharmacol 2011;79:42-50.

(30) McCloskey C, Rada C, Bailey E, et al. The inwardly rectifying $\mathrm{K}+$ channel KIR 7.1 controls uterine excitability throughout pregnancy. EMBO Mol Med 2014;6:1161-1174.

(31) Lindheimer MD, Richardson DA, Ehrlich EN, et al. Potassium homeostasis in pregnancy. J Reprod Med 1987;32:517-522.

(32) Brainard AM, Korovkina VP, England SK. Potassium channels and uterine function. Semin Cell Dev Biol 2007;18:332-339.

(33) von Elm E, Altman DG, Egger M, et al. STROBE Statement: linee guida per descrivere gli studi osservazionali. Ter Evid Based 2008;1:1-8.

(34) Bailey RL, Pac SG, Fulgoni VL, et al. Estimation of Total Usual Dietary Intakes of Pregnant Women in the United States. JAMA Netw Open 2019;2:e195967.

(35) Comerford KB, Ayoob KT, Murray RD, et al. The Role of Avocados in Maternal Diets during the Periconceptional Period, Pregnancy, and Lactation. Nutrients 2016;8.
(36) Vitale SG, Marilli I, Rapisarda AM, et al. Cellular and biochemical mechanisms, risk factors and management of preterm birth: state of the art. Minerva Ginecol 2014;66:589-595.

(37) Wolak T, Sergienko R, Wiznitzer A, et al. Low potassium level during the first half of pregnancy is associated with lower risk for the development of gestational diabetes mellitus and severe pre-eclampsia. J Matern Fetal Neonatal Med 2010;23:994-998.

(38) Wolak T, Shoham-Vardi I, Sergienko R, et al. High potassium level during pregnancy is associated with future cardiovascular morbidity. J Matern Fetal Neonatal Med 2016;29:1021-1024. (39) Birukov A, Andersen LB, Herse F, et al. Aldosterone, Salt, and Potassium Intakes as Predictors of Pregnancy Outcome, Including Preeclampsia. Hypertension 2019;74:391-398. (40) Laganà AS, Vitale SG, Sapia F, et al. miRNA expression for early diagnosis of preeclampsia onset: hope or hype? J Matern Fetal Neonatal Med 2018;31:817-821.

(41) Yılmaz ZV, Akkaş E, Türkmen GG, et al. Dietary sodium and potassium intake were associated with hypertension, kidney damage and adverse perinatal outcome in pregnant women with preeclampsia. Hypertens Pregnancy 2017;36:77-83.

(42) Salman H, Shah M, Ali A, et al. Assessment of Relationship of Serum Neurokinin-B Level in the Pathophysiology of Pre-eclampsia: A CaseControl Study. Adv Ther 2018;35:1114-1121. (43) Budak MS, Kahramanoglu I, Vitale SG, et al. Maternal abdominal subcutaneous fat thickness as a simple predictor for gestational diabetes mellitus. J Perinat Med 2019.

(44) Word RA, Tang DC, Kamm KE. Activation properties of myosin light chain kinase during contraction/relaxation cycles of tonic and phasic smooth muscles. J Biol Chem 1994;269:2159621602.

(45) Casteels R, Kuriyama H. Membrane potential and ionic content in pregnant and non-pregnant rat myometrium. J Physiol 1965;177:263287.

(46) Crankshaw DJ, Crosby DA, Morrison JJ. Effects of the KIR7.1 Blocker VU590 on Spontaneous and Agonist-Induced Contractions of $\mathrm{Hu}-$ man Pregnant Myometrium. Reprod Sci 2017;24:1402-1409. 
(47) Wright PD, Kanumilli S, Tickle D, et al. A High-Throughput Electrophysiology Assay Identifies Inhibitors of the Inwardly Rectifying Potassium Channel K ir 7.1. J Biomol Screen 2015;20:739-747.

(48) Greenlee M. Narrative Review: Evolving Concepts in Potassium Homeostasis and Hypokalemia. Ann Intern Med 2009;150:619. (49) Godard C, Gaillard R, Vallotton MB. The Renin-Angiotensin-Aldosterone System in Mother and Fetus at Term. Nephron 1976;17:353-360.

(50) Dong N, Xu H-G. Estimating Renal Function in Pregnancy. JAMA 2019;321:2136.

(51) Conti-Ramsden FI, Nathan HL, De Greeff A, et al. Pregnancy-Related Acute Kidney Injury in
Preeclampsia: Risk Factors and Renal Outcomes. Hypertens Dallas Tex 1979 2019;74:1144-1151. (52) Davison JM, Dunlop W. Renal hemodynamics and tubular function normal human pregnancy. Kidney Int 1980;18:152-161.

(53) Martínez M, Soldevila B, Lucas A, et al. Hypothyroidism during pregnancy and its association to perinatal and obstetric morbidity: a review. Endocrinol Diabetes Nutr 2018;65:107113.

(54) Soma-Pillay P, Nelson-Piercy C, Tolppanen $\mathrm{H}$, et al. Physiological changes in pregnancy. Cardiovasc J Afr 2016;27:89-94.

(55) Fadiloglu E, Bulut Yuksel ND, Unal C, et al. Characteristics of obstetric admissions to intensive care unit: APACHE II, SOFA and the Glasgow Coma Scale. J Perinat Med 2019;47:947-957. 